\title{
Indonesian Spelling Errors in the Description Text
}

\author{
Harzoni \\ IAIN Bengkulu \\ Harzoni300@gmail.com \\ Suhirman \\ IAIN Bengkulu \\ suhirmn@gmail.com \\ Ixsir Eliya \\ IAIN Bengkulu \\ eliyaixsir@gmail.com
}

\begin{abstract}
The purpose of this study was to describe the form of spelling errors in the descriptive text of class VII A students of SMP Negeri 05 Bengkulu City. This study uses a qualitative research type with a descriptive approach. Based on the discussion of research data on the analysis kesalaha $\mathrm{n}$ spelling of Indonesian in the essay on pembelaja ran B ahasa Indonesian students of class VII A Junior High School 05 Bengkulu city, the writer can give the conclusion that in general the students of class VII A SMPN 05 Kota Bengkulu have not mastered the use of letters, word writing, the use of punctuation in writing essays. Classically, students have not been able to understand the general use of Indonesian spelling (PUEBI)in writing an essay. Because students still have difficulty in understanding the use of Indonesian spelling. The results of the study concluded that letter errors, writing errors, punctuation errors, from the data that the authors found there were errors in the use of capital letters and italics, words with affixes, errors in writing abbreviations and acronyms, periods, commas, colons, hyphens., dash. As for errors in the use of letters of the alphabet, vowels, consonants, diphthongs, combinations of consonants and bold letters, basic words, repeated forms, word combinations, word decapitation, particles, numbers and numbers, pronouns, articles, slashes, question marks, exclamation marks, ellipsis marks, quotation marks, single quotation marks, brackets, square marks, and abbreviations were not found errors from the research data.
\end{abstract}

Keywords : Indonesian Spelling Error, Description Text

\section{A. Introduction}

Descriptive text is a paragraph where the main idea is conveyed by clearly describing the object, place, or event that is being the topic to the reader. The following are the linguistic rules of descriptive text: 1) Use nouns according to the topic being described. Such as: school, home, my teacher, my friends, etc. 2) Use phrases that contain nouns. For example, he is a humble principal, etc. 3) Contains descriptive adjectives. Such as: one diligent student, two white socks, etc. 4) Contains Transitive verbs to provide subject information. Like: the student is wearing a blue white uniform, etc. 5) Contains a verb (feeling, opinion) with the aim of expressing the author's personal view on the subject. Like: I think it's a smart cat, I believe the book is cheap, etc. 6) Contains adverbs to provide additional information about 
the object. Such as: quickly, at home, in the canteen, etc. Contains figurative language in the form of parables or metaphors. Such as: the skin is soft like silk thread, etc. ( Yuksinau.id, 2020).

The author finds various errors that can be found in the descriptive text essays of students of SMP Negeri 05 Bengkulu City to be one proof that students of SMP Negeri 05 Bengkulu City still find many errors in the use of language, especially in terms of spelling in writing an essay. In fact, students are required to apply the correct spelling in accordance with the Indonesian Spelling (EBI) rules. Spelling errors are one type of language error in written language. This greatly affects the quality of a writing. good writing. If there are many spelling errors and without paying attention to the correct spelling, the content of the writing cannot be conveyed to the reader clearly and precisely (Ahmad Zubaidi et al, 2019). The spelling errors are also still found in the descriptive text essays of students of SMP Negeri 05 Bengkulu City. Therefore, this study was conducted to determine the level of spelling errors in writing descriptive text essays for students of SMP Negeri 05 Bengkulu City.

The use of correct spelling is one of the factors that determine the perfection of written language. Spelling is a set of rules that govern how to symbolize speech sounds, how to separate and combine these symbols in a language. According to the Big Indonesian Dictionary (KBBI) spelling is the rule of how to describe sounds (words, sentences and so on) in writing (letters) and the use of punctuation marks ( Didah Nurhamidah, 2018).

Based on the opinions above, it can be concluded that an error is the use of language that deviates from the language rules that apply in that language. Mistakes in the use of letters are often made in terms of writing, special sized and shaped letters (larger than ordinary letters), usually used as the first letter of the first word in a sentence, the first letter of a personal name, and so on. To determine spelling errors in this study, the types of spelling errors that will be examined include: Capital letters, italics, bold letters, full stop, comma, hyphen, dash, slash. Therefore, the researchers was interested in conducting the research on identifying Indonesian spelling errors in descriptive text.

\section{B. Research methodology}

This study uses a qualitative research type with a descriptive approach. This research intends to understand the phenomena of what is experienced by the research subjects such as behavior, perceptions, motivations, actions, etc. holistically and by means of descriptions in the form of words and special language in a special natural context and by utilizing various scientific method. This type of research will be used to get an overview of Indonesian spelling errors (EBI) in student description texts ( David Budianto. Rm, 2019).

This research was conducted at SMP Negeri 05 Bengkulu City located on J1. RE Martadinata No.5, Pagar Dewa, Kec. Broad, Bengkulu City. The time of the research was 
carried out at SMP Negeri 05 Bengkulu City on September 3, 2020 for 1 month. This research was conducted on students of class VII A of SMP Negeri 05 Bengkulu City. The total number of students consisted of 32 students who experienced a decline in their activeness in learning, especially in Indonesian subjects. Data collection techniques are the most strategic step in research because the main purpose of research is to obtain data, namely observation and documentation. In testing the validity of the data, researchers use triangulation techniques, namely checking the validity of data that utilizes something other than the data for checking purposes or as a comparison against the data, and the most widely used triangulation technique is by checking through other sources. There are several kinds of data triangulation by utilizing the use of sources, methods, investigators and theories, namely, source (data) triangulation, method triangulation, investigative triangulation, theoretical triangulation ( Moleong, Lexy J, 2007).

Based on the type of research used is descriptive, then the collected data will be analyzed using qualitative analysis, namely by describing the research results in words or sentences so that the author describes in depth the results of the research in accordance with the actual situation that occurred. in the field. Data analysis in qualitative research includes the following stages, data reduction, data presentation, conclusion drawing and verification ( Bungin Burhan, 2004).

\section{Results and Discussion}

1. Results

a. Misuse of Letters

\section{Capitalization Error}

Capital letters are used as the first letters of words at the beginning of sentences, the first letters of direct quotations, the first letters in expressions related to the first letters of the names of nations and languages. Based on the results of the analysis, the authors found the form of spelling errors in writing capital letters, there were 372 errors from 32 students' essays, but only three errors were displayed. Indonesian spelling errors in the descriptive text of class VII A SMP NEGERI 05 Bengkulu City, namely the capital letter that should be used as the first letter at the beginning of the sentence, however, is not used or is not applied, resulting in an Indonesian spelling error in writing capital letters. This needs to be corrected so that the same mistakes don't happen again. From the data analysis, the writer found many errors in capital letters. 


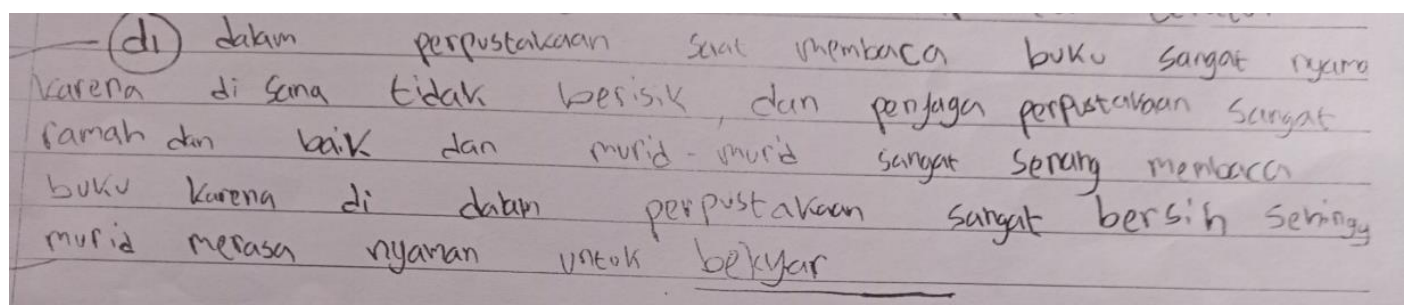

\subsection{Data}

From data 1.1, it can be seen that there are forms of spelling errors in Indonesian, namely the author does not use letters at the beginning of sentences using capital letters. Supposedly, at the beginning of the sentence capital letters should be used because this writing rule has been standardized. So, if the author does not follow the rules for writing the correct spelling or in accordance with PUEBI, it can be said to be a form of Indonesian spelling error.

\section{Italics Error}

One example of mistakes made by the author in writing italics, namely writing italics in foreign languages.

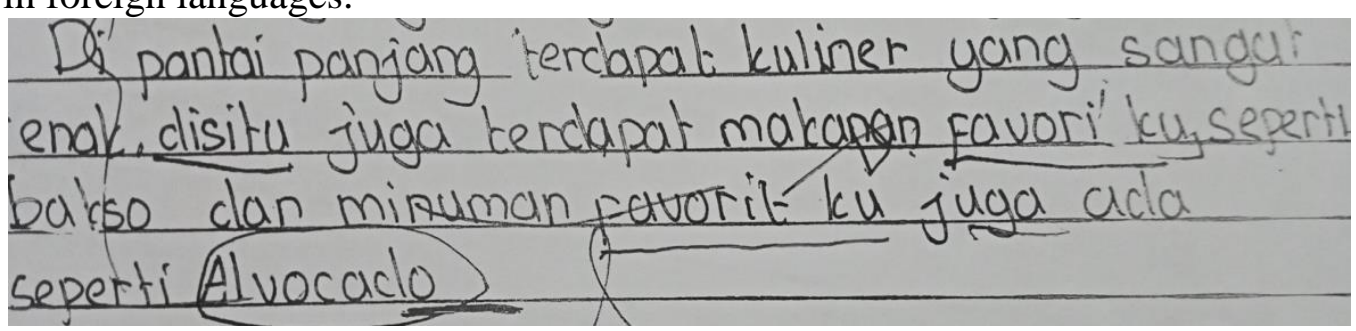

\section{Data 1.4}

From data 1.4, it can be seen that the form of Indonesian spelling errors, namely the author does not use italics in writing the hero's name. Italics are used to write book titles, specify letters, and write foreign language expressions. There are rules that govern when italics should and should not be used.

\section{b. Word Writing Error}

\section{Preposition Error}

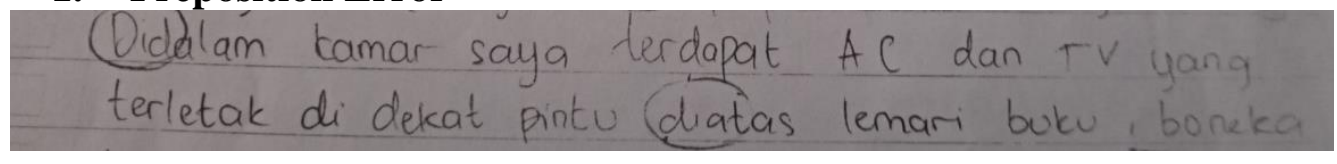

\section{Data 1.8}

In data 1.8, the researcher found that the form of preposition writing errors, such as di, to, and from, was written separately from the word that followed it. The words "In my room there is AC and TV located near the door above the bookcase, dolls" in the data above should be separated, the word should be written, namely "In my room there is AC and TV located near the door above the cupboard book, doll" because it is more appropriate to use it in the sentence. So, the writer must be able to sort out the words that are more appropriate to use so that mistakes in writing the words with incomplete or inappropriate affixes can be avoided. 


\section{Abbreviations and Acronyms Errors}

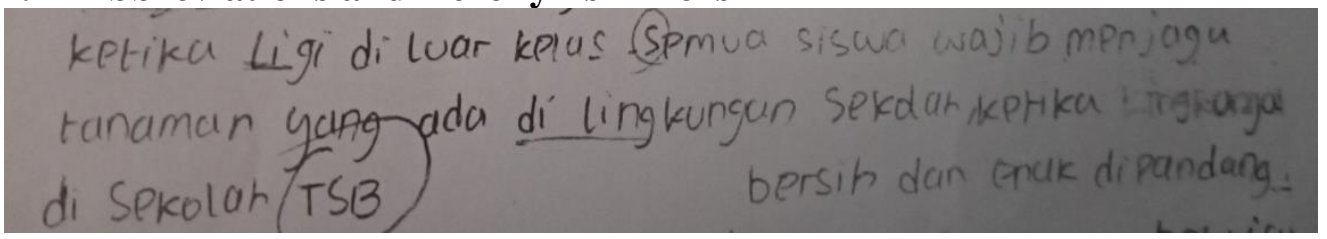

Data 2.1

In data 2.1, researchers found forms of writing errors in abbreviations and acronyms. Abbreviations consisting of three or more letters followed by a period. The word "plants that exist in the school environment when the environment in the TSB school" should use a period. the words that should be written, namely "plants that exist in the school environment when the environment is in the TSB school." because it is more appropriate to use it in the sentence. So, the writer must be able to sort out the words that are more appropriate to use so that mistakes in writing less or inappropriate affixes can be avoided .

\section{c. Error Using Punctuation}

1. Error using period (.)

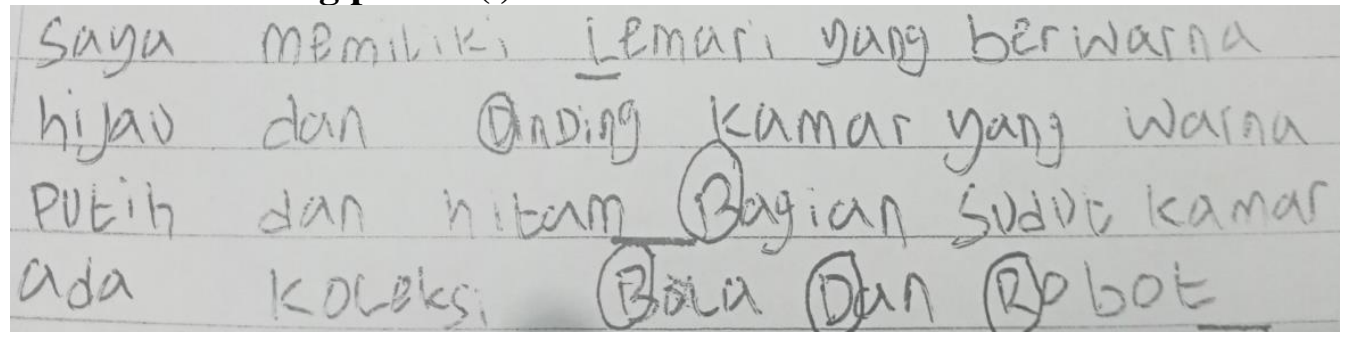

Data 2.4

In data 2.4, the author finds the form of Indonesian spelling errors in writing periods. The author does not put a period between elements that should be used by a period, thus causing the sentence to be ineffective and needs to be corrected to make it effective. The author finds the error form does not use a period.

\section{Error Using Comma (,)}

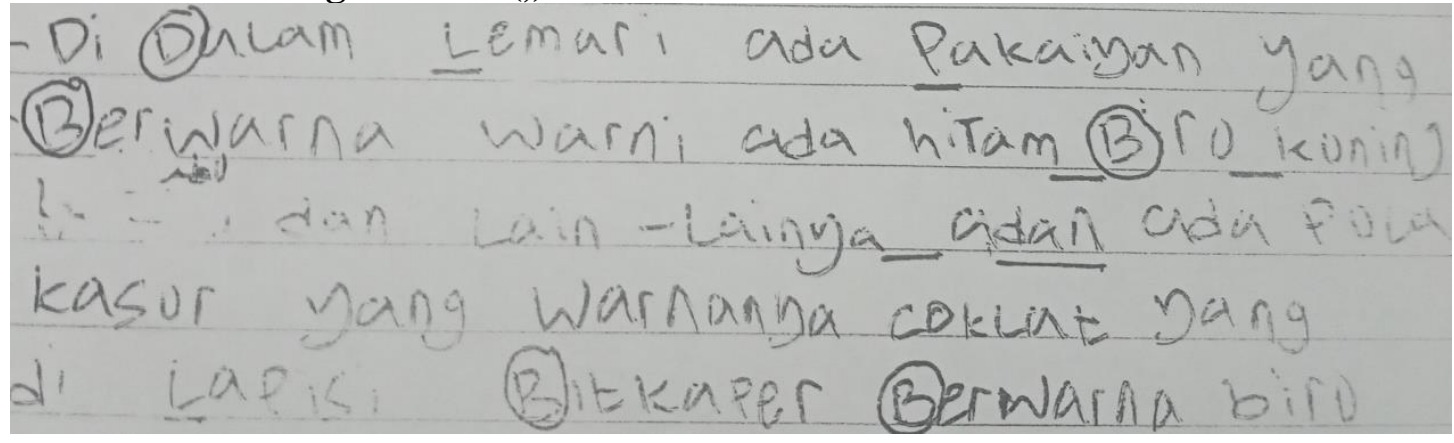

Data 2.7

From data 2.7, it can be seen that there is no use of commas after words or connecting expressions between sentences at the beginning of sentences. Whereas in the rules for the use of commas, it is emphasized the use of commas in connecting expressions between 
sentences. A comma (,) is used between elements in a detail or numeration, separating one equivalent sentence from the next equivalent sentence preceded by words such as and but, to separate the clause from the main clause if the clause precedes the main clause and so on. other.

3. Error Using Colon (:)

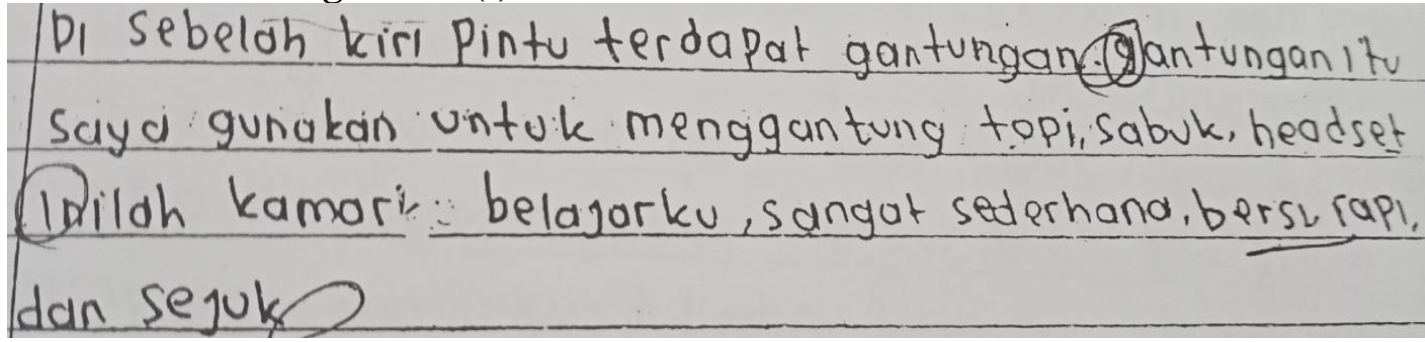

Data 3.1

A colon is used at the end of a complete statement followed by details or explanations. In data 3.1, the writer finds an error in the use of colons. The correct writing of the data should say "I use the hanger to hang my hat, belt, headset, this is my study room, very simple, clean, neat, and cool". The correct writing in student essays should be "I use the hangers to hang: hats, belts, headsets, this is my study room, very simple, clean, neat, and cool".

\section{Error Using Hyphen (-)}

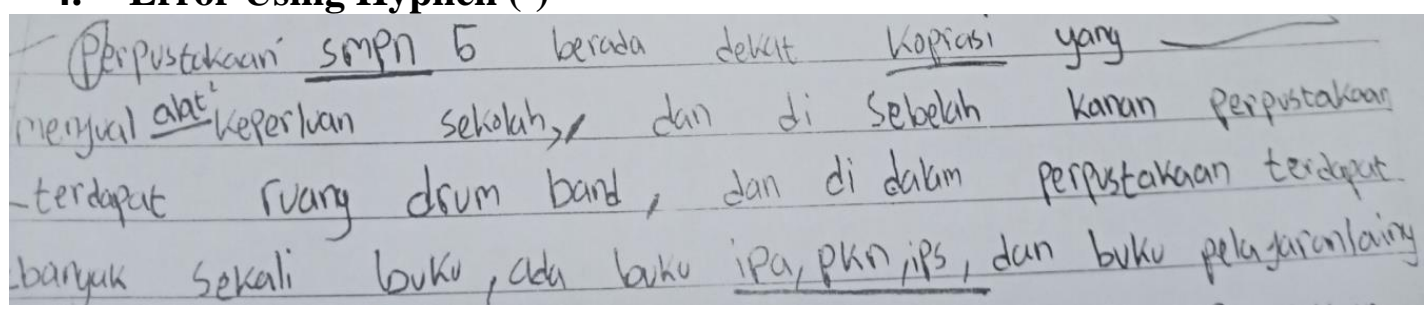

Data 3.4

In the words alat 2 should also use a hyphen (-) and way menulisnyatidak was shortened due hyphen to connect basic syllables separated by a line break, so that the sentence be Library SMP Negeri 5 are close cooperative that sells tools for school.

\section{Error using dash $(-)$}

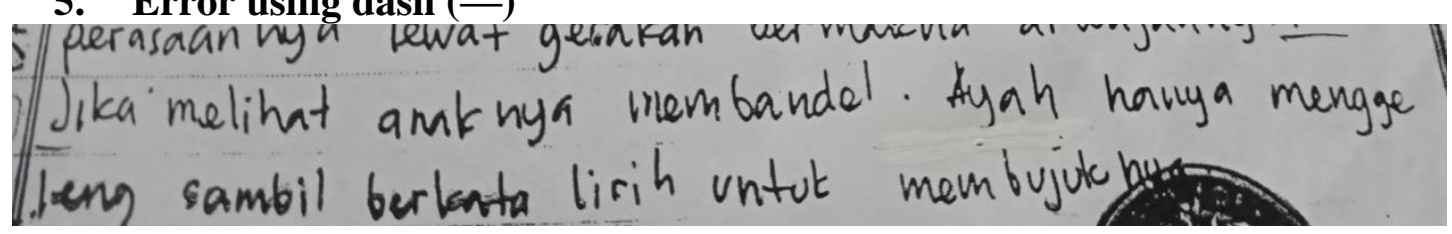

\section{Data 3.8}

A dash can be used to emphasize the existence of an appositional statement or other information. In the words Dad just shook his head while speaking softly to persuade him, he should also use a dash (--) and how to write it must use a dash (--) so that the sentence becomes Dad just shook his head and said softly to persuade him. The use of dashes has several functions and rules that are quite unique compared to other punctuation marks. The 
use of certain types of hyphens in sentences may be unfamiliar or not often used. However, you can use it to clarify the meaning of certain words or sentences.

\section{Discussion}

Spelling errors are one of the problems that are often done by students in writing. Without mastering spelling students are not able to write properly and correctly. These errors can be identified through the error analysis process which is a work procedure used to find out what the mistakes made by students in writing an essay. This is in line with the opinion of Ellis (in Tarigan, 2011:60-61) explaining that error analysis is a working procedure used by researchers or professors which includes sample collection, identification of errors contained in the sample, explanation of the error.

Tarigan (2011: 60) states, Error analysis has steps which include: 1. Sample collection,

2. Fault identification,

3. Explanation of the error,

4. Classification of errors, and

5. Error evaluation

Furthermore, Tarigan (2011: 63-64) mentions the new working steps of error analysis through selection, sorting, and combining, namely (1) collecting data, (2) identifying and classifying errors, (3) rating errors, (4) explaining errors, (5) predicting or predicting areas or linguistic things that are prone, and (6) correcting errors.

This study was conducted to determine the form of Indonesian spelling errors made by students of SMP 05 Bengkulu City in a descriptive text essay. The data in this study are in the form of written essays that have been made by class VII A students of SMP Negeri 05 Bengkulu City. The results of the analysis examined from students' essays contained 545 errors of words from 32 students' essays, namely capital letter writing errors, italics writing errors, preposition errors, abbreviations and acronyms errors, commas, colons, hyphens. Based on the results of research on data analysis, it was concluded that in writing student description texts there were forms of Indonesian spelling errors, such as errors in using letters, writing errors in words, and errors in using punctuation marks. The results showed that the Indonesian spelling errors in this study were caused by a lack of understanding of students in correct writing or writing in accordance with PUEBI, so that students still misunderstood correct and incorrect writing. An example of the data found, many students used a comma in writing that only consisted of two elements, even though according to the guidelines this was not justified because they did not follow the correct writing guidelines. The cause of Indonesian spelling errors can also occur due to the lack of carefulness of students when writing descriptive text essays. 


\section{Conclusion}

From the results of the implementation of this study, it was concluded that discussing three problems, namely errors in the use of letters from the data that the authors found there were errors in the use of letters, namely errors in the use of capital letters and errors in the use of italics, while for errors in the use of letters of the alphabet, vowels, consonants, diphthongs, combinations consonants, bold letters, no errors were found in the research data.

The results of the analysis examined from student essays contained 545 word errors from 32 student essays, namely capital letter writing errors, italic writing errors, preposition errors, abbreviations and acronyms errors, periods, commas, colons, hyphens,

\section{Bibliography}

Burhan, B. (2004). Qualitative Research Methods . Jakarta: PT Rajagrafindo Persada.

Chaer, A. (2013). Indonesian Language Development. Jakarta: Rineka Cipta.

Firdausa, M., et al . (2017). The Use of Indonesian Spelling in Writing Descriptions for Class VII Students . Journal of Words (Language, Literature, and Its Learning ).

Gunawan, H.I., \& Retnawati, S. (2017). Analysis of Spelling Errors in Student Papers of Economics Education Faculty of Teacher Training and Education, Pamulang University. Journal of Education, Law and Business, Vol.1 No.V, December .

Alexander. (2008). Research and Social Methods (Quantitative and Qualitative). Jakarta: Gaung Press.

Moleong. L. J. (2007). Qualitative Research Methodology, Bandung: PT Remaja Publisher Rosdakarya Offset, Bandung.

Nurhamidah. D. (2018). Analysis of Spelling Errors in Faculty Student Writings Economics and Business of Uin Syarif Hidayatullah Jakarta. Thesis: Indonesian Literature Study Program, Faculty of Letters, Pamulang University.

Pitaloka, T. et.al. (2019). Analysis of Spelling Errors in Compiling Elementary School Descriptive Text Essay. Journal of Elementary Education and Children, 2(1), 21.

Pranowo. (2014). Language Learning Theory. Yogyakarta: Student Library.

Prawisti, D.N. (2012). Analysis of Spelling Errors in the Writings of Class VII Students of SMP N 2 Depok. S kripsi: Study Program Indonesia Literature Faculty of Language and Art, State University of Yogyakarta, Depok .

Rom, D.B. (2010). Enhanced Punctuation and Spelling Error Analysis (Eyd) in Karangadn in Learning Indonesian for Class V Students at Mi Alislam, Bengkulu City. Thesis of S1 Teacher Education Study Program for Madrasah Ibtidaiyah Faculties of Tarbiyah and Tadris, Bengkulu State Islamic Institute, Bengkulu.

Rukhayah, U. Analysis of Spelling Errors in Paragraph Texts in Indonesian Language Learning at the Islamic Economics and Business Faculty, IAIN Surakarta”, Thesis: TBI, Adab and Language Faculty, IAIN Surakarta, Surakarta .

Tarigan, H.T. (2011). Teaching of Language Error Analysis. Bandung: Space Bandung.

Yuksinau.. 2020. Descriptive text. (online), ( https://www.yuksinau.id/teks-desisi-pengertian struktursample/\#: :text=Example\%20Text\%20Description,Pengertian\%20Teks\%20De skripsi, while \%20d reveals\%20dalam\%20teks\% 20te , accessed 13 August 2020) 
Zubaidi, A. et al. 2019. Analysis of Indonesian Spelling Errors in Thai Student Narrative Writings at Muhammadiyah University, Jakarta. Thesis on Indonesian Language and Literature Education, Faculty of Education, University of Muhammadiyah Jakarta. 